\title{
Implementation Analysis of Corporate Social Responsibility (CSR) in Alleviating Poverty at Oil-Rig Location (Case study in Rahayu Village, Soko Sub-District, Tuban Regency)
}

\author{
Ahmad Syu'aib Jamali ${ }^{1,}$, Darsono Wisadirana ${ }^{2}$ and Mardiyono $^{3}$ \\ ${ }^{1}$ Universitas Brawijaya \\ Malang, Indonesia \\ ${ }^{2}$ Universitas Brawijaya \\ Malang, Indonesia \\ ${ }^{3}$ Universitas Brawijaya \\ Malang, Indonesia \\ *Corresponding author's email: jam.4.lee [AT] gmail.com
}

\begin{abstract}
Oil and gas sectors have become important elements in the economy of Indonesia. The question now is, what can be done by private owned company which has the advantage of very large exploration to overcome poverty? Can corporate social responsibility programs or Corporate Social Responsibility (CSR ) become one important solution in reducing poverty? Joint Operating Body Pertamina Petrochina East Java (JOB-PPEJ) JOB PPEJ operational activities gave rise to the Flare (fire hot) which directly impact on the environment override Rahayu village, the site of its formation. Therefore, it is the duty of the company to carry out CSR programs through the estate as a form of social and environmental responsibility especially in Rahayu village in order to realize sustainable development in the village. In this study, researchers used a type of descriptive research methods with qualitative approach. In conclusion, 1) The implementation of CSR programs in the JOB - PPEJ had already a positive impact or benefit to society in particular Rahayu Village. 2) CSR programs aimed at tackling the problem of poverty is not a top priority. So that the rural poor have not been so feel real economic impact on their lives. 3) The success implementation of CSR program JOB - PPEJ is influenced by several supporting and inhibiting factors. The supporting factors to the success implementation of CSR programs in improving the economic standard RTSM around oil drilling sites are the amount of funds allocated by the company for these and other programs that will be implemented. While the factors that hinder the CSR program in improving the economic standard RTSM around oil drilling sites is the lack of proper coordination between the company, the village and the poor.
\end{abstract}

Keywords - Corporate Social Responsibility (CSR), Joint Operating Body PetroChina East Java (JOB-PPEJ)

\section{INTRODUCTION}

Sumodiningrat (1998:26) suggest that poverty is a problem within development, a problem with multidimensional nature and related with social, economy, cultural and other aspects. Poverty was marked by isolation, backwardness, and unemployment, which would increase to become imbalances between region, between sectors, and between (people's) classes [1]. United Nations (UN) has added that poverty was characterized by lack of participation in decision making and participation in civil, social and cultural life (Barrientos, 2010).

Poverty was individual and or household inability to meet its basic needs. Individual poverty would refer to individual inability to meet their basic life needs [2].

Poverty was not only measured by income, but it also encompass broader things, such as vulnerability of people or a group of people, either male or female, to become poor; and limited access of poor people to decide public policy that would affects their life.

Poverty that entwined to societal life was more structural than individual. They were poor not because they were lazy, but more because social structure was hold them back, thus they cannot use the available resources for them. 
Poverty alleviation program was basically aimed to accelerate poor people reduction in all regions of Republic of Indonesia. Broadly speaking, coverage of poverty alleviation program that was expected to be developed in most regions was:

1. Empowerment and development of human ability related with education, health, and improvement in other basic needs.

2. Empowerment and development of human ability related with improvement in environmental, residential, housing and its support facilities.

3. Empowerment and development of human ability related with business venture, employment, and other aspects that could increase revenue.

Implementation of poverty alleviation program which was done since 1998 until now was, in general, able to decrease poverty in Indonesia which marked 47,97 millions or about 23,43\% in 1999 to become 30,02 millions or about $12,49 \%$ in 2011. Based on Worldfactbook, BPS and World Bank, in global level, poor people reduction in Indonesia was the fastest among other countries. It was noted that during 2005 to 2009, Indonesia was able to lower its decreasing average in number of poor people per year about $0,8 \%$, much higher than other countries such as Cambodia, Thailand, China and Brazil which only attain $0,1 \%$ per year [3].

Government as an entity that rules the economy has made a policy to be used as main regulation for companies to run their business along with the existed rules. This regulation was stated in Statute No. 40 of 2007 concerning Limited Company which in article 74 regulates social and environmental responsibility.

Based on this statute, all state owned companies or foreign companies which located in Indonesia and has run its operation was given a responsibility to conduct an activity called Corporate Social Responsibility (CSR). CSR is something concerned with the obligation to create a good relationship between company, government and citizen or member of society.

CSR is a program where one of its objectives would be to empower the people. Basic principle of CSR is poor people empowerment so that they could be freed from poverty. CSR concept was often identified as the method of community development that was implemented by companies with the term ComDev. In a formal definition according to UN in Gunawan (2008: 21-22)., Community Development (CD) is “... a process whereby the efforts of Government are united with those of the people to improve the social, cultural and economic conditions in communities". Generally speaking, Community Development is a broad concept, which include various effort by applying theories and practices such as civic leadership, activist, and also by involving citizen and professional to improve every aspects of local community. In its practice, implementer would identify the problem, learning the local resources, analyze the local power structure, and identify people's needs and other things within the community.

Many ways or methods have been done by companies in Indonesia to conduct CSR. However, it would be better if the existed CSR program can be ongoing and right on target. Process to achieve ideal CSR will take quite a long time, and cannot be done instantly. Therefore, cooperation was required from all parties involved and not just from one particular institution or firm.

Basically Indonesia is a developing country that rich in natural resources, either renewable or unrenewable. One of the natural resources in Indonesia was oil and gas resources. Oil and gas sector has become the important element in Indonesian economy. Indonesia was once listed as one of the oil exporter in international world. Besides, crude oil and gas is natural resources as the gift from God for people of Indonesia.

Economy imbalances, low education, and rule of economy assets by certain people or group, was one of the cause for poverty. The question now is, what could a private firm do, with large business profit, to address/alleviate this poverty? Can a Corporate Social Responsibility (CSR) program become one of the important solutions in an effort to reduce poverty?

Joint Operating Body Pertamina Petrochina East Java or simply called JOB-PPEJ is one of the joint venture company which run in oil industry in Indonesia. JOB-PPEJ has been operating in Rahayu village, Tuban regency since February 27th, 1988 until the third transition to become JOB-PPEJ in July 4th, 2002, until now. When oil exploration was done initially on the field of MUDI in Rahayu village, Soko sub-district, Tuban regency in 1997, JOB-PPEJ has generated lots of revenue for this country. In its first operational, production could reach $18.000 \mathrm{barrel} /$ day. Even during 2000, oil production from MUDI field has culminated, producing $22.000 \mathrm{barrel} / \mathrm{day}$. At this time, MUDI field is still operating though its production has drastically lowered, to produce only 1.500 barrel/day.

Prior to company's operation, most people in the area $(70 \%)$ was categorized as poor people and the remaining $(30 \%)$ was middle class. There was no effort to address poverty in the village, either from local government or provincial or central government. Company operation which started in 1997 was not yet able to give 
effective effect toward community's economy improvement. However, slowly it started to show improvement from year to year.

Objectives of this study were to found out, to analyze and to interpret the focus of attention related with:

1. Implementation of CSR program that has been done by JOB-PPEJ

2. Effect of this implementation and its benefit for poor people who reside near oil rig location

3. Factors that supports and constraints CSR program to improve economy of poor people near oil rig location.

\section{RESEARCH METHOD}

This study used qualitative descriptive method with case study approach. Qualitative data was primary and secondary data including words and acts, and also additional data such as documents and others [4].

Study site was in Rahayu village, Soko sub-district, Tuban regency since this village located in Ring 1 of oil-rig location done by Joint Operating Body Pertamina-Petrochina (JOB-PPEJ). Rahayu village was chosen as study site since the village was in Ring 1 which is the region who received direct impact of the activities run by the company. While oil production was abundant in Rahayu village, there were lots of poor household reside near the field.

\section{Data Collection Method}

Informant selection technique in this study was done purposively (informat from JOB-PPEJ, Rahayu village officials, management staff of KUB Mekarjaya and from poor household in Rahayu village). For the first data collection, in-depth interview was held to obtain primary data from informants. Second data collection involving observation to complete and cross-checking data obtained from interview with informants at study site. The third data collection effort was by conducting documentation or collecting data that was already compiled in documents such as amount of poor household at study site as argument support in deciding study site, several other supporting data from the internet such as poverty condition in Indonesia in general, statistical data according to BPS, data about recipient of Raskin program from BULOG Sub Divre Bojonegoro, and others.

Table 1. Number of recipient of Raskin program in Rahayu village

\begin{tabular}{|c|l|c|c|}
\hline No & $\begin{array}{c}\text { Name of sub-village } \\
\text { (Dusun/Dukuh) }\end{array}$ & $\begin{array}{c}\text { Year } \\
\mathbf{2 0 1 2}\end{array}$ & $\begin{array}{c}\text { Year } \\
\mathbf{2 0 1 4}\end{array}$ \\
\hline 1 & Kayunan & 196 & 195 \\
\hline 2 & Sarirejo & 64 & 64 \\
\hline 3 & Delik & 22 & 22 \\
\hline 4 & Gandu & 81 & 81 \\
\hline & Total & $\mathbf{3 6 3}$ & $\mathbf{3 6 2}$ \\
\hline
\end{tabular}

Source: Processed primary data

From the above table, it was indicated that recipient for Raskin program in 2014 was no different than recipient for those in 2012, this showed that poverty in this village did not change.

\section{Data Analysis Method}

This study used qualitative approach, thus its data analysis also used those in qualitative approach as suggested by (Miles and Huberman, 2014) concerning how to analyze qualitative data. Data was in the form of words and not numbers, thus data analysis was separated into three activities line: (a) data condensation; (b) data presentation; (c) inference drawing [5].

\section{RESULT AND DISCUSSION}

Geographically, Rahayu village was located in Soko sub-district of Tuban regency. This $629.641 \mathrm{~m}^{2}$ village was bounds by Kebonagung village at the north, Sandingrowo village at the south, Karangtinoto village at the east and Sumurcinde village at the west [6]. Rahayu village was located in the peripheral area of sub-district and the main region for oil industry also has major potential in agriculture. 
Authority of implementation of CSR program in JOB-PPEJ has become the responsibility of Public Relation \& LC (Land Condemnation) Section. This department section was led by a supervisor whose task was to help Field Administration Department to deal with relationship with local people and regional government also to maintain good relationship between the company and stakeholders. LC (Land Condemnation) has the responsibility to deal with land exemption and land-use rent.

CSR program in JOB-PPEJ has not yet become the main focus of company's activities. The company has try to comply with Statute No. 40 of 2007 concerning Limited Company and PP No. 47 of 2012 concerning Social and Environment Responsibility of Limited Company however it was not supported with effort to help reducing poverty within the area. This should, of course, also become the main focus of the company, since the role of local government in reducing poverty was highly limited. The company should also realized that their existence was not only affecting natural conservation, but also that their existence was very important for those people who lived nearby.

Referring to Statute that regulate company social responsibility which are Statute No. 25 of 2007, Statute No. 40 of 2007, PP No. 47 of 2012, ISO 26000 also other regulation concerning CSR, JOB-PPEJ itself has already implement its company social responsibility through implementation of CSR programs that has been determined by the company. CSR program was implemented by JOB-PPEJ since its initial year that is since 1988. CSR program was implemented in JOB-PPEJ has its own terms. For example, in 2012, JOB-PPEJ used the term PSPO (Program Sosial Penunjang Operasional), and then transformed into PPO (Program Penunjang Operasional) in 2013, and PKPO (Program Kegiatan Penunjang Operasional) also CR (company responsibility) as terms used for company social responsibility implementation used in 2014

The existence of CSR programs implemented by JOB-PPEJ was not only to improve company image in the eye of the people but it was already the obligation and ethics of the company. CSR program was implemented so that company activities run smoothly by also paying attention toward its surrounding conditions such as its social, economy, and environmental conditions, along with 3P concept (people, profit, planet) in CSR. CSR programs run by JOB-PPEJ were also involving those three important aspects.

CSR programs determined by JOB-PPEJ wouldn't be beneficial if it did not actually implement through a real actions. In implementation of CSR programs in JOB-PPEJ, there were several stages including planning stage, stakeholders, outcome stage, and monitoring and evaluation stage of the implementation.

\section{Implementation of CSR Programs by JOB-PPEJ}

a. Planning CSR Program of JOB-PPEJ

CSR programs determined by JOB-PPEJ were basically run through several stages. Planning, approval, implementation, and its benefit received by people as target (outcomes). Every stages has its own mechanism, starting from planning who involved several parties, allocation and funding distribution for CSR until implementation of the program.

In determining CSR programs that was going to be implemented by JOB-PPEJ, the company would hold prior coordination with local people through local meeting (musyawarah/rembug desa). First of all, JOB-PPEJ would conduct CSR assessment through social mapping in the targeted area that would become the consideration material for program determination in the area. From mapping result, JOB-PPEJ has the broad description about program plan and CSR budget about to be used for implementation. Proposal for CSR program can be suggested by the people itself.

Mapping conducted by JOB-PPEJ together with expert team was so that the program can be target oriented and in accordance with the need of the people. After mapping, JOB-PPEJ could create programs along with its budget and then offered to village people through village officials.

In the village itself, a committee to monitor the implementation of CSR programs, known by the name of Komite Pemberdayaan Masyarakat Desa (KPMD) was once formed. However, this committee was no longer in function since its status was in question and there was no policy regarding this from the new Village Chief. Thus, monitoring the implementation of CSR programs was given to LPMD [Lembaga Pemberdayaan Masyarakat Desa].

LPMD along with the people and village officials would conduct local meeting (musyawarah/rembug desa) to follow up the program offered by JOB-PPEJ. This meeting was done to synchronize CSR program of JOB-PPEJ with program suggested by village people. This synchronization was meant so that program held by JOB-PPEJ did not overlap with local government program for the related village. 
CSR programs determined by JOB-PPEJ were also adjusted to its people's needs and not just referring to company's interest. However, not all programs proposed by the people can be accepted by JOB-PPEJ. The point is, JOB-PPEJ will select all kind of program that was in their budget and able to be implemented by them.

In this case, JOB-PPEJ is not the approval authority whether the proposed program can be implemented completely, but only acts as operator, while proposal approval would still handled and processed by SKK MIGAS. This institution has the authority to approve or decline proposal for CSR programs proposed by JOB-PPEJ. Therefore, not every program proposed by JOB-PPEJ toward SKK MIGAS would gain approval since it would be adjusted to the available budget and the benefit of the program. If SKK MIGAS approved the proposed program, budget for this CSR program can be liquidify and implementation of the program can be conducted.

Implementation of CSR programs by JOB-PPEJ was involving all stakeholders, particularly the people that coordinate by LPMD and village chief. This is in accordance with the principle of CSR program compiling in JOBPPEJ whereas participative and subjective implementation was attained through direct involvement of the people in the activities processes.

\section{b. Implementer of CSR programs of JOB-PPEJ}

In JOB-PPEJ itself, implementer for CSR program would involved JOB-PPEJ particularly PR \& LC section, expert team from various university who cooperate in mapping and master plan making for CSR program, the community itself, SKK MIGAS as the decision maker for approval, and also local government. All these parties should conduct a good coordination so that the pre-determined CSR program can be succeeded and right on target also did not overlap with other program conducted by local government.

i. JOB-PPEJ

In this case, JOB-PPEJ particularly PR \& LC section has become the main party who hold responsibility for CSR. It was responsible for CSR program starting from its planning, decision making, program compiling, strategy determination, implementation and monitoring and evaluation for CSR activities.

ii. The Community

Community involvement in CSR program has also become the main priority for JOB-PPEJ since the main target of CSR is the local people thus an active community in giving aspiration and implementation of CSR program was needed.

iii. SKK MIGAS

In this case, SKK MIGAS is the decision maker. Through approval from SKK MIGAS, implementation of CSR program can be initiated. If WP\&B proposed by JOB-PPEJ, in which CSR program was included in it, was approved, then the program can be realized.

iv. Local government

Based on the observation done while being within JOB-PPEJ, it can be seen that the role of local government, particularly Tuban regency in implementation of CSR program has a very limited contribution. Almost all CSR activities were done by JOB-PPEJ with the people. JOB-PPEJ was also cooperate with the local government before deciding what CSR activities to be implemented in order to synchronize which activities fall under the responsibility of the government and which activities fall under the responsibility of JOB-PPEJ, thus there were no overlapping activities between local government and the company.

Sub-local government (village government) through village chief has also involved in formulating the proposal about activities that was going to be conducted. LPMD acts to monitor the implementation activities of the CSR program.

\section{c. Target of Program Implementation}

In implementation of CSR program, JOB-PPEJ has already determined who would become the object or target of this implementation. CSR program was run in several regions that suffer the impact of JOB-PPEJ's activities. For Tuban and Bojonegoro regency, there were 9 (nine) sub-district and 42 (forty two) villages which classified into 3 (three) groups, those were, region that become the center of drilling and well which carry impact and direct impact status (MUDI DA and A), region that potentially developed for well area and drilling (SKWT DA and A), also region where mining pipes was passing through the area (PIPA).

CSR program implemented by JOB-PPEJ was not only centered in Tuban and Bojonegoro regency (MUDI, SKWT, and PIPA), but it was done in all area who became the operational location of JOB-PPEJ such as in several sub-districts and villages in Tuban, Bojonegoro, Gresik and Lamongan regencies.

\section{d. Implementation Result of CSR Program in Rahayu village}

Based on the existed data, CSR program has been implemented in Rahayu village every year. Program implemented would covers 6 sectors, which are social and economy, health, infrastructure, education, compensation and 
reconciliation, also government and public relation. Regarding CSR for environmental sector, the re was no particular program for environmental sector in CSR program of JOB-PPEJ, however, it was conducted through compensation and reconciliation program. For infrastructure, it was directed toward environmental improvement and provision of infrastructure needed by the community. JOB-PPEJ has also consistently implement CSR program. This can be seen from its ongoing program every year such as:

i. Infrastructure sector

JOB-PPEJ has conduct CSR program in infrastructure sector consistently to support infrastructure needs in Rahayu village. This can be seen from programs that have been realized since 2008 until 2012. In 2008, there were aid for road repair and maintenance in Dusun Sarirejo, mosque renovation in Dusun Kayunan and clean water installment in Dusun Sarirejo. In 2009 there were continuation of road repair and maintenance in Dusun Sarirejo. In 2010, there were aid for road repair and maintenance in Dusun Kayunan, plaster (turap) construction in Rahayu village also lighting infrastructure for village road. While in 2011, it was focused on renovation and development, such as building village office, building road block wall, embankment repair, relocation of SDN 1 and 2 Rahayu village, also road repair and river normalization. For 2012 there were also continuation for village office, mosque, and school renovation, paving stone development, and water canal repair.

ii. Compensation and Reconciliation sector

Compensation and reconciliation program is a program conducted continuously every year. Aid given from 2008 to 2012 was compensation for CPA flare impact. However, in 2011, other than this flare impact compensation, there was also aid in providing health facilities, health facilities, also reforestation. Flare impact compensation was also continued in 2012. This compensation was done $7 \mathrm{x}$ in a year with nominal Rp. 500.000,- per family head for Ring 1 area, Rp. 400.000,- per family head for Ring 2 and Rp. 300.000,per family head for Ring 3 . However, this compensation was not given in cash but in the form of basic need package.

iii. Government and Public Relation sector

Aid in government and public relation was frequently given compare to other sector. This aid was beyond the pre-determined CSR program because there was request by local people and local or regency government. From 2008 to 2012 there was no significant change every year, that is by becoming sponsorship for various activities, either community or government activities. However, in 2009 to 2012 there was more additional aid such as aid in building material, and in 2010 there was also alms for certain group of people, aid for flood victim, and donation for victim of natural disaster.

\section{Impact of CSR program implementation and its benefit for the people near oil rig location Collection sector}

CSR program implementation has, in overall, given positive impact for the people in Rahayu village. Changes before and after the program was implemented was felt by the people themselves. Below were impacts of CSR program from JOB-PPEJ.

a. Social-Economy aspect

Aid from CSR of JOB-PPEJ in social-economy has given positive impact for the people, particularly for those who join Kelompok Usaha Bersama (KUB). This positive impact were easy access in borrowing capital without using collateral, with low interest rate, inexpensive installment, easy access to fertilizer and agricultural products, payment over fertilizer and agricultural products can be done during harvest.

However, this positive impact was only felt by those who join KUB Mekarjaya. While, those who did not join KUB cannot feel the benefit of the program.

Other than the existence of KUB Mekarjaya who give positive impact toward the community, there was also positive impact felt by poor people from the artesian well built for irrigation purpose. There were 2 artesian well build for irrigation purpose in Rahayu village. This irrigation system can water 25 hectare field. Before irrigation system was installed, harvest can only be done once a year, but after irrigation system was implemented, harvest can be done twice a year. This created employment for farm worker in Rahayu village. There were about 160 farm worker involved in paddy planting season and they could obtain more revenue from 25 hectare field.

b. Educational aspect

CSR of JOB-PPEJ for education was also felt by people in Rahayu village. But unfortunately, there was only a few of them that could enjoy the benefit, since there was only a few students who receive scholarship from JOB-PPEJ. It was less than 50 students.

Other than scholarship program, the company was also renovated TK PKK Harapan. This renovation was done due to comfortability, thus physical renovation of the school building was done. Relocation of SDN Rahayu 1 and 2 was also done by the company. This was done because SDN Rahayu 1 and 2 was no longer comfortable to be use as school building due to its vicinity with CPA flare location thus it should be relocated. The new school 
building was already finished but was started to be used in February 2015. This relocation was expected to bring more benefit, particularly so that students were no longer disturbed by flare impact during their study.

New school location was quite far from the flare, thus flare impact would only felt indirectly and making all member of the school felt more comfortable.

c. Health aspect

CSR program in health aspect has quite tremendous benefit for the people. Several change in health infrastructure occurs in Rahayu village prior to 2010 and after 2010 can be seen from Table 2 below.

Table 2. Change in Health Infrastructure in Rahayu Village

\begin{tabular}{|l|l|l|}
\hline & $<2010$ & $>2010$ \\
\hline $\begin{array}{l}\text { Clean } \\
\text { Water }\end{array}$ & $\begin{array}{l}\text { - There was only manual well } \\
\text { - Artesian well was used in early } \\
2000\end{array}$ & $\begin{array}{l}\text { - Using artesian well } \\
\text { - Clean water reservoir }\end{array}$ \\
\hline $\begin{array}{l}\text { Health } \\
\text { Facilities }\end{array}$ & $\begin{array}{l}\text { - Before, citizen should go to Soko } \\
\text { sub district health community } \\
\text { center which is quite far from the } \\
\text { village } \\
\text { - In 1985 there was already village } \\
\text { midwife }\end{array}$ & $\begin{array}{l}\text { - Health post was operated in } 2010 \\
\text { - Health post was build. }\end{array}$ \\
\hline
\end{tabular}

Based on the table above, it can be seen that prior 2010, there was only manual well in Rahayu village, this has made it harder for the people to have clean water. Artesian well was started to be used in early 2010 . The existence of JOB-PPEJ was also give benefit to them particularly concerning financial aid to build the well and water reservoir in 2011. This aid has give access for people in Rahayu village to obtain clean water, because from this water reservoir pipes were installed to distribute it to households.

Table above also showed that prior to 2010, people in Rahayu village should walk far enough to obtain medical treatment, since there was no health post in their village. However, after 2010, government started to build health post in Rahayu village. Contribution of JOB-PPEJ in this matter was by giving aid in the form of medication and facilities in the health post.

CSR program conducted by JOB-PPEJ during 2008-2012 has already spread to various aspects, but none of it was specifically aimed for poor people.

Existence of poor people near oil-rig location was not yet involved in implementation of CSR program by oil company. Thus, CSR programs implemented was yet directly touched them (poor people) unless for its free medication program.

Therefore, these poor people were like trapped in poverty as written by Chambers (1987) which covers powerlessness, vulnerability, physical weaknesses, poverty and isolation. How could they fix their economy condition if they were not involved in CSR program conducted by JOB-PPEJ. escape from.

Below was description concerning poverty trap which made poor people in Rahayu village was difficult to

1. Powerlessness

Although people could propose the type of CSR program to be implemented by the company, most of the activities proposed was to give broad impact for all the people and not specifically arranged for poor people.

Activities proposition from the village was dominated by village elite through village chief and its officials. Local meeting was only formality, whereas it shows that all people were involved in proposition for CSR program activities.

2. Vulnerability

Poor people condition which was not accommodated in CSR programs has made them more vulnerable either economically or socially. They become less respectful toward the company since they felt that their existence was not acknowledged by the company.

3. Physical weaknesses

Low education level of poor people has made them difficult to obtain suitable employment. Thus, they would mostly take up any work that existed. One time they would become farm worker, laborer or any kind of work just to obtain money for food.

4. Poverty 
The company paid less attention to poor people condition which made them stays poor. There should be training activities in the village which involved poor people particularly to improve their skill.

5. Isolation

The existence of oil company near the village did not made them easier to access the company. This was like isolating them from the oil company who generate lots of profit for the country.

\section{Factors which support and constraint CSR programs to improve economy level of poor household near oil rig location \\ Based on study result and discussion above, it can be concluded that factors which support and constraint CSR programs to improve economy level of poor household near oil rig location were:}

a. Poor people were not involved in every activities of CSR program except in free medication.

Although poor people was also invited in local meeting to plan activities proposed to the company, most result would be dominated by the interest of village elites. For the last 3 year, largest portion of CSR activities were infrastructure which proposed by village elites.

b. From sub local government (village government) there was no initiative to create a proposal for poor people and to use their manpower.

There was no initiative from village government to analyze the need and activities that would directly affect poor people. Their priority was more directed toward infrastructure, such as village infrastructure, road block plaster, irrigation or mosque development. As those who directly related with the people, village representatives should be good facilitator to accommodate the need of poor people.

c. Poor people themselves felt that they should not be involved in any CSR programs.

Poor people's enthusiasm in every local meeting was quite high. However, they felt that it was nothing more than a routine activity or their obligation as a member of the society. Whether their proposition was accepted or not was not a problem for them since they felt that CSR programs that has been done was quite good and reflect aspiration of the people.

Several factors to support CSR programs to improve economy level of poor household near oil-rig location were:

a. There was willingness from the company to conduct training for the people and it has been done previously or in other villages.

Before initial capital was given toward Kelompok Usaha Bersama (KUB), the company has conduct trainings toward KUB management staff regarding how to manage the fund they were about to receive. Training was done in Malang and all KUB management staff was participating in it.

b. Amount of CSR fund allocated by the company.

This was supposed to be the positive value to alleviate poverty near oil rig location. The company has tried the best they could to allocate fund for CSR programs although authority to approve the programs didn't lie in their hand. Amount of fund for CSR should be used for activities directed to community's economy empowerment in the village.

Economy condition for poor people in Rahayu village did not experience significant improvement and tend to stagnant. This was because CSR programs under implementation was felt only by some of the poor people and not yet generate significant effect to their economy condition.

CSR programs of JOB-PPEJ were implemented as the realization of social responsibility toward environment. There should be changes and shift concerning CSR programs that was done as participation to help government in its effort to alleviate poverty.

\section{CONCLUSION}

Based on the study result and analysis above, it can be concluded that:

1. JOB-PPEJ as the company who allocate CSR fund has already implements the program in accordance to the company guidance. CSR programs were running well although most of the program was allocated for infrastructure or general facilities within the village. CSR program was not yet aimed to deal with poverty alleviation.

2. CSR programs under implementation have generated positive impact for poor people near oil rig location. The actual impact would be that farm worker in the village could obtain employment during paddy planting season and the people in KUB Mekarjaya can obtain loan for business capital or agricultural products without using collateral.

3. Constraint factors within CSR program to improve economy level of poor household near oil rig location was lack of coordination between the company, village representatives, and poor people. Factors which 
support the success of this program were amount of fund allocated by the company for CSR programs under implementation.

\section{SUGGESTION} institution:

Based on findings within this study and analysis, below were suggestions from the author for the related

1. Tuban regency government should also participate in formulating what kind of activities that would beneficial for poor people near oil rig location. Regency (local government) should try to initiate discussion with village representative (sub-local government) in formulating these activities and did not allow them to compile their own activities plan. This should be done so that village representative could have mature knowledge and insight concerning CSR management.

2. Village representative (sub-local government) should start to prioritize economy empowerment in formulating activities plan and reduce the proposition related with infrastructure. Economy empowerment was also expected to be able to reach poor people in particular.

3. Oil company JOB-PPEJ should often communicate to village representative that CSR programs would be more beneficial if directly reaching out to poor people and able to empower poor people within the village.

\section{ACKNOWLEDGMENT}

We would like to say thank you to Dr. H. Soekarwo, SH, M.Hum as East Java Governor, Dean of Social and Political Science Faculty in Brawijaya University, Prof. Dr. Ir. Darsono Wisadirana, M.S which also act as Primary Advisor, and Head of Magister Program for Social and Political Science, Prof. Dr. Ir. Sanggar Kanto, M.Si, and Dr. Mardiyono, MBA as Secondary Advisor.

\section{REFERENCES}

[1] Sumodiningrat, Gunawan, Building the People's Economy, Pustaka Pelajar, Yogyakarta, 1998.

[2] Faturrochman and Marcelius Molo, Characteristics of Poor Households in Yogyakarta Special Region, Populasi, Vol. 5, Nomor 1, Yogyakarta, 1994.

[3] TNP2K, Statistical Official News, http:// tnp2k.go.id/program/sekilas, 2013.

[4] Moleong Lexi J., Qualitative Research Methodology, PT. Remaja Rosdakarya, Bandung, 2012.

[5] Miles, Matthew B dan Huberman, Qualitative Data Analysis, United State Of America, State University, Arizona, 2014.

[6] Kantor Desa Rahayu, Profile of Rahayu Village, 2013. 